\title{
Miszelle
}

Julene Abad Del Vecchio*

\section{On the Use of carcer at Stat. Achil. 1.625}

https://doi.org/10.1515/phil-2021-0100

Keywords: carcer, Achilles, horse-racing metaphor, Statius' Achilleid, metapoetics

Halfway through the Achilleid, Achilles bemoans his apparent loss of masculinity whilst cross-dressed. During the Bacchic rituals on Scyros, and just prior to the reaffirmation of his maleness via Deidamia's rape, he asks himself how long he will be able to endure the tricks of his "timid mother" (Stat. Achil. 1.624: timidae ... parentis), and "dissipate the first flower of virtue caged in an unwarlike prison" (1.625-626):

\section{primumque imbelli carcere perdes}

florem animi?

That Scyros is an emasculating and stifling carcer there is little doubt: the island is envisioned as an oppressive cosmos, which stands for the all-embracing, maternal urge that keeps him from war. ${ }^{1}$ I suggest, however, that Statius is here playing on a double sense of the word carcer. The poet is not only relying on the prison metaphor: he is also evoking the word's meaning that specifically designates the starting place of the racecourse, referring to the enclosed stalls where horses would be kept before running. ${ }^{2}$

1 Examined by V. Rimell, The Closure of Space in Roman Poetics: Empire's Inward Turn, Cambridge 2015, 262-263; 266-267. On Scyros, see F. Ripoll, "La construction d'un pays imaginaire: l'île de Scyros dans l'Achilléide de Stace”, Bulletin de l'Association Guillaume Budé 1, 2008, 146-162. I use the text of Statius, Achilleid, ed. O. A. W. Dilke, Cambridge 1954. Translations are mine.

2 ThlL III 434.29-63. In the ThlL, the Achilleid's passage is instead given as an example of carcer standing metonymically for the captivity of a vita otiosa, cf. III 438.40. Commentators do not consider this image as a possibility, cf. P. Papinio Stazio, L'Achilleide, testo critico e commento a cura di S. Jannaccone, Firenze 1950; Dilke (n. 1); Stace, Achilléide, F. Ripoll et J. Soubiran, Louvain/Paris/

*Corresponding author: Julene Abad Del Vecchio, University of Manchester, Department of Classics, Ancient History, Archaeology and Egyptology, Samuel Alexander Building, The School of Arts, Languages and Cultures, Oxford Rd, Manchester, M13 9PL, UK, E-Mail: julene.abaddelvecchio@manchester.ac.uk 
The interpretation which I proffer is in harmony with the passage's context, with its immediate subject matter, and with the poet's own previous descriptions of Achilles/the Achilleid. In Silva 4.7, Statius complains of the lack of inspiration for "[his] Achilles” (Stat. Silv. 4.7.22-24: tardius sueto venit ipse Thymbrae / rector et primis meus ecce metis / haeret Achilles, "the lord of Thymbra himself arrives slower than usual, and look! my Achilles is stuck at the first turning post"). ${ }^{3}$ The description of the Achilleid as making the first turn on the racecourse is, as Henderson noticed, ${ }^{4}$ strikingly appropriate to describe a poem that has stopped after its first book, and most importantly, it illustrates well Statius' usage of chariot imagery to reflect on poetic endeavours, as well as the designation of Achilles himself as a steed. ${ }^{5}$ In the Achilleid, the hero donning feminine clothes for the first time is likewise compared by the narrator to an unruly horse - once free to roam the fields - being tamed (Stat. Achil. 1.277-282). Considering this equine parallel, the iunctura imbellis carcer, unique to Statius, could be interpreted as a sort of poetic enallage, since it is the fortis equus that gets to race (cf. the well-known Ennian horse reprised at Ov. Ars am. 3.595-596). The use of the metapoetic adjec-

Dudley, MA 2008; Publio Papinio Stazio, Achilleide, a cura di G. Nuzzo, Palermo 2012. Among some translations, see that of G. Rosati in Stazio, Achilleide, a cura di G. R., Milano 1994, 129: "in questa dolce prigione"; the superb rendering of D. R. Slavitt, Broken Columns: Two Roman Epic Fragments: The Achilleid of Publius Papinius Statius and The Rape of Proserpine of Claudius Claudianus. With an Afterword by David Konstan, Philadelphia 1997, 21: "pillowed prison”; Ripoll and Soubiran (this n.) 127, "prisonnier d'un havre de paix"; Statius, Achilleid, transl. by S. Lombardo with an introduction by P. J. Heslin, Indianapolis/Cambridge 2015, 23: "in unmanly captivity”; G. Bitto, Vergimus in senium: Statius’ Achilleis als Alterswerk, Göttingen 2016, 293 talks of a “verweichlichten Gefängnis”. An anonymous reviewer brings to my attention a parallel for the double sense at Val. Fl. 1.610-11, where the personified storm winds as horses (or riding on horses) are released from Aeolus' cave (often referred to as carcer, cf. Verg. Aen. 1.52-54), a prison and a starting gate. The carceres were two sets of six stalls divided in the middle by the porta pompae and had wooden gates (cancelli) from which the horses would dash, cf. W. K. Quinn-Schoffield, "The alba linea in the Circus Maximus”, Latomus 25, 1966, 861-866, at 861-862, also useful for historical attestations.

3 Text from Statius, Silvae IV, ed. K. M. Coleman, Oxford 1988. See R. R. Nauta, “The recusatio in Flavian Poetry”, in: R. R. Nauta/H. van Dam/J. J. L. Smolenaars (eds.), Flavian Poetry, Leiden 2006, 21-40, at 30-33 for this recusatio linked to the Achilleid's proem, alongside the re-assessment proffered by J. Penwill, “Imperial encomia in Flavian Epic”, in: G. Manuwald/A. Voigt (eds.), Flavian Epic Interactions, Berlin 2013, 29-54.

4 J. Henderson, “Form Remade/ Statius' Thebaid”, in: A. J. Boyle (ed.), Roman Epic, London 1993, 162-191, at 164.

5 On Statius' use of chariot imagery, see Coleman (n. 3) 203; H. Lovatt, Statius and Epic Games. Sport, Politics and Poetics in the Thebaid, Cambridge 2005, 24-25; S. Rebeggiani, "The Chariot Race and the Destiny of the Empire in Statius' Thebaid”, Illinois Classical Studies 38, 2013, 187-206. 
tive imbellis (cf. Achil. 1.207) adds a layer of irony. ${ }^{6}$ Achilles, in denoting the starting gate as "unwarlike", draws our attention to the fact that the adjective may be better suited to define him instead, cross-dressed and shying away from war. The irony underscores even more profoundly the chasm between his current situation and his epic aspirations, the monologue's overall crux (Achil. 1.624-639).

In the light of the poet's recurrent use of horse-racing symbolism to describe his poetic undertakings and the Achilleid's protagonist, Achilles' pensive words can be seen to assume a metapoetic tone. Scyros represents the beginning of Achilles' life, here envisaged as the gate from which he will begin the race, "a time of eager expectation both from spectators and from the horses". ${ }^{7}$ Achilles' words in his soliloquy, a crucial turning point in the narrative, conjure up the fitting image of a horse raring to go, a bellator equus (Verg. G. 2.145) which has been confined, unwillingly and for too long, to an unwarlike carcer, antithetical to the vast, bellicose spaces longed for by the hero (Achil. 1.627-629). ${ }^{8}$ Aptly, the signal of the start of a race was sometimes given by the blast of a trumpet (Ov. Met. 10.652-653: signa tubae dederant, cum carcere pronus uterque / emicat, "the trumpets had given the race's signal, when each, leaning forward, flashed forth from the stall..."), ${ }^{9}$ the same military instrument Ulysses needs to use to lure Achilles out of his disguise (Achil. 1.725), which is then played by Agyrtes during the hero's decisive transformation into his epic self, the once more unbridled horse (Achil. 1.875-876: ... cum grande tuba sic iussus Agyrtes / insonuit, "when Agyrtes, as instructed, gave forth a loud sound from his trumpet”).

Although the two meanings of carcer may elicit a temporal mismatch, as "prison" indicates a forced and lasting stay, whereas "starting gate" a momentary, fervent state, the double meaning may be actualized by different focalizations. Whilst Achilles the first-person narrator views himself as a prisoner, via the 'starting gate' metaphor the poet ironically draws our attention to Achilles' imminent (sexual) release, setting the scene for the Ovidian scenario that ensues, as we

\footnotetext{
6 The adjective traditionally describes poetry in polar opposition to the epic genre (e.g., Hor. Carm. 1.6.10; Ov. Am. 3.15.19). In the Achilleid, it suitably represents Lycomedes' palace, detached from all things epic (Achil. 1.207).

7 In the words of B. J. Gibson (ed.), Statius Silvae 5, Oxford 2005, 192 on the horse-racing imagery in Stat. Silv. 5.2 and its appropriateness for Crispinus, who is beginning his political career.

8 Gibson (n. 7) 192 provides ample examples of the metaphorical use of carcer as a starting point from Ennius onwards (Enn. Ann. 79-83 Sk.). On the Roman cliché of the metapoetics of chariots, poets as charioteers, and the metaphor's suitability for structural readings of beginnings, middles, and endings of texts, see now the overview by T. J. Nelson, "Équitation, Char", in: J.-P. Guez/F. Klein/J. Peigney/É. Prioux (eds.), Dictionnaire des images du poétique anciennes, Classiques Garnier, Paris, forthcoming.
}

9 Text as given in P. Ovidi Nasonis Metamorphoses, rec. R. J. Tarrant, Oxford 2004. 
are about to witness Deidamia's rape (compare the elegiac charioteer of Ov. Am. 3.2). ${ }^{10}$ The end of the soliloquy shows his resolve to prove his manliness through sexual violence (Achil. 1.639), confirmation of which follows at once (Achil. 1.640642). The metaphor flags to the audience the prompt outcome of his monologue, and suitably conveys the urgency of Achilles' impulse.

It is, however, worth bearing in mind the following reflection of Rimell's here, since an elegiac scenario may not be so readily disconnected from the world of war: "we are to learn from this poem that rape is not just a crime that happens in war or on the edge of war, but what war does and is; that, in other words, those realms we are taught to view as separate, or to be separated (domestic and military violence, closed-in elegy and roaming epic, the mother and the man) are undividable and indeed symbiotic". ${ }^{11}$ Deidamia's rape is Achilles' first act as warrior, and the first act of war. The metaphor can in fact disclose more worrying expectations when read against the end of Georgics 1, where an inexperienced auriga (Octavian?) cannot keep hold of the chariot which has burst through the carceres (Verg. G. 1.511-512: saevit toto Mars impius orbe, / ut cum carceribus sese effudere quadrigae, "and wicked Mars rages throughout the world, as when from the starting gates the chariots issue forth..."). ${ }^{12}$ The moments that signal war are portrayed by Lucan (1.293-295) and Silius Italicus (8.278-283) in similar terms that convey impending conflict, as they equate, respectively, Caesar and the Roman mob to horses out of the gates. The parallels suggest that Achilles' keenness may foretell a likewise uncontrollable scenario, and that his pent-up potential, first released through the rape, will eventually be irrepressible. ${ }^{13}$

Be that as it may, interpreting carcer as a "starting gate" here, in addition to “prison”, helps the reader visualize the hero's restlessness, encapsulating his allconsuming amor belli that urges him - the wild horse domesticated - finally to

10 The poet's use of double meanings can be seen once more in the monologue, where perdes / florem animi may be ambiguously referring to the loss of virginity.

11 Rimell (n. 1) 258-259, emphasis hers, cf. also 267-270. On Achilles' rape as an unsuccessful assertion of masculinity, see P. J. Heslin, The Transvestite Achilles, Cambridge 2005, 258-276.

12 Text of P. Vergili Maronis Opera, rec. R. A. B. Mynors, Oxford 1969. On the passage, see Virgil, Georgics. Volume 1: Books 1-2, ed. by R. F. Thomas, Cambridge 1988, 154; A. J. Boyle, "In medio Caesar: Paradox and Politics in Virgil's Georgics”, Ramus 8, 1979, 65-86, at 65-66, and M. Dewar, "Octavian and Orestes in the Finale of the First Georgic", CQ38, 1988, 563-565. For the employment of the singular rather than the more proper use of the plural, see Servius' commentary on poetic license at Verg. Aen. 1.54 (... unde vero erumpunt quadrigae, 'carceres' dicimus numero tantum plurali, licet plerumque usurpet poeta, ut est 'ruuntque effusi carcere currus'), often occurring in verse (e.g., Tib. 1.4.32; Ov. Am. 3.2.9; 66).

13 On the Achilleid's “about-to-erupt potential”, see Rimell (n. 1) 255; 258-259. 
burst out of his carcer's confines, ready to start in earnest the epic race around the corner.

Acknowledgements: I am very grateful to Bruce Gibson, Adalberto Magnavacca and Alison Sharrock for their valuable comments, and to the journal's anonymous referees for their advice. 